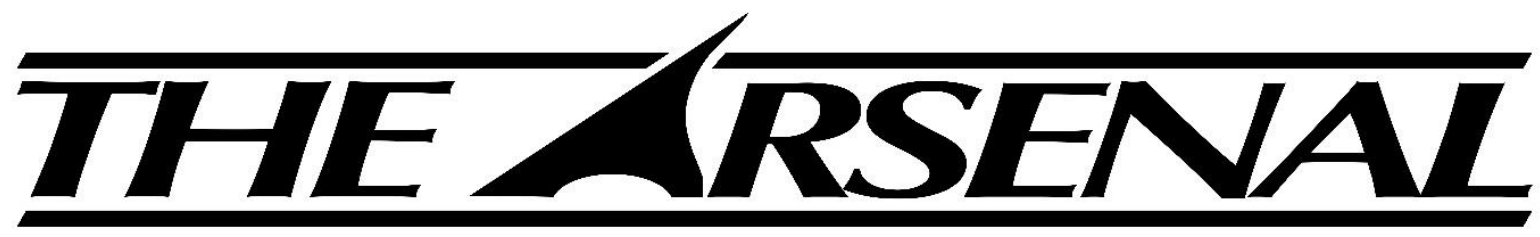

Augusta University's Undergraduate Research Journal

ISSN 2380-5064 | The Arsenal is published by the Augusta University Libraries | http://guides.augusta.edu/arsenal

Volume 3, Issue 2 (2020)

Special Edition Issue

PERFLUOROOCTANOIC ACID (IN THE PRESENCE

OF FETAL BOVINE SERUM) INDUCES

PROLIFERATION IN ER $\alpha$ POSTIVE AND ER $\alpha$

NEGATIVE BREAST CANCER CELL LINES

Victoria Gaw, Manderrious Glenn, and Jennifer Cannon

\title{
Citation
}

Graw, V., Glenn, M., \& Cannon, J. (2020). Perfluorooctanoic acid (in the presence of fetal bovine seruym) induces proliferation in ER $\alpha$ Positive and ER $\alpha$ Negative breast cancer cell lines. The Arsenal: The Undergraduate Research Journal of Augusta University, 3(2), http://doi.org/10.21633/issn.2380.5064/s.2020.03.02.11

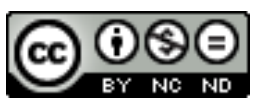

(C) Graw, Glenn, and Cannon 2020. This open access article is distributed under a Creative Commons Attribution NonCommercial-NoDerivs 2.0 Generic License (https://creativecommons.org/licenses/by-nc-nd/2.0/). 


\section{Perfluorooctanoic Acid (in the Presence of Fetal Bovine Seruym) Induces Proliferation in ER $\alpha$ Positive and ER $\alpha$ Negative Breast Cancer Cell Lines}

Presenter: Victoria Gaw (Poster Presentation)

Authors: Victoria Gaw, Manderrious Glenn, and Jennifer Cannon

Faculty Sponsor(s): Jennifer Cannon, $\mathrm{PhD}$

Department Affiliation: Biological Sciences

Funding: Augusta University CURS Student Research Grant, Department of Biological Sciences

\section{ABSTRACT}

Perfluorooctanoic acid (PFOA) is a synthetic chemical belonging to a larger group of fluorotelomers. These compounds have been used in the production of both industrial and consumer products as surfactants and are environmentally persistent pollutants. While the long-term effects of PFOA are largely unknown, there is increasing evidence suggesting it to be an endocrine disruptor. Studies have shown that PFOA binds to and activates peroxisome-proliferator-activated receptor $\alpha(\operatorname{PPAR} \alpha)$, which can regulate the expression of other genes and receptors. Previous experiments in our lab demonstrated that PFOA treatment of MCF-7 breast cancer cells (an ER $\alpha$-positive cell line) decreased expression of ER $\alpha$ mRNA and protein, and decreased cell viability by $\sim 20 \%$ within $48 \mathrm{~h}$ of treatment compared to DMSO controls. However, these cells were treated in the absence of fetal bovine serum (FBS). When we repeated these experiments without serum withdrawal, we initially noted a tendency towards increased proliferation in MCF-7 cells treated with $50 \mu \mathrm{M}$ and $100 \mu \mathrm{M}$ PFOA at both $24 \mathrm{~h}$ and $48 \mathrm{~h}$ compared to control. To further examine the role of ER $\alpha$ in this PFOA-induced proliferation, we carried out additional experiments in MCF-7 cells along with experiments in another ER $\alpha$-positive cell line, T47D, as well as an ER $\alpha$-negative cell line, MDA-MB-23.

Received: 01/31/2020 Accepted: 02/17/2020

Correspondence: Victoria Gaw, Augusta University, $112015^{\text {th }}$ St. Augusta, GA 30912, vgaw@augusta.edu 